\title{
GEOLOGIC MAP OF THE SURFICIAL DEPOSITS OF THE TOPOPAH SPRING QUADRANGLE, NYE COUNTY, NEVADA
}

\author{
By W C Swadley and D.L. Hoover
}

Prepared in cooperation with the U.S. DEPARTMENT OF ENERGY

\section{DISCLAIMER}

\begin{abstract}
This report was prepared as an account of work sponsored by an agency of the United States Government. Neither the United States Government nor any agency thereof, nor any of their employees, makes any warranty, express or implied, or assumes any legal liability or responsibility for the accuracy, completeness, or usefulness of any information, apparatus, product, or process disclosed, or represents that its use would not infringe privately owned rights. Reference herein to any specific commercial product, process, or service by trade name, trademark, manufacturer, or otherwise does not necessarily constitute or imply its endorsement, recommendation, or favoring by the United States Government or any agency thereof. The views and opinions of authors expressed herein do not necessarily state or reflect those of the United States Government or any agency thereof.
\end{abstract}




\section{DISCLAIMER}

Portions of this document may be illegible in electronic image products. Images are produced from the best available original document. 
DEPARTMENT OF THE INTERIOR

U.S. GEOLOGICAL SURVEY
TI89 010910

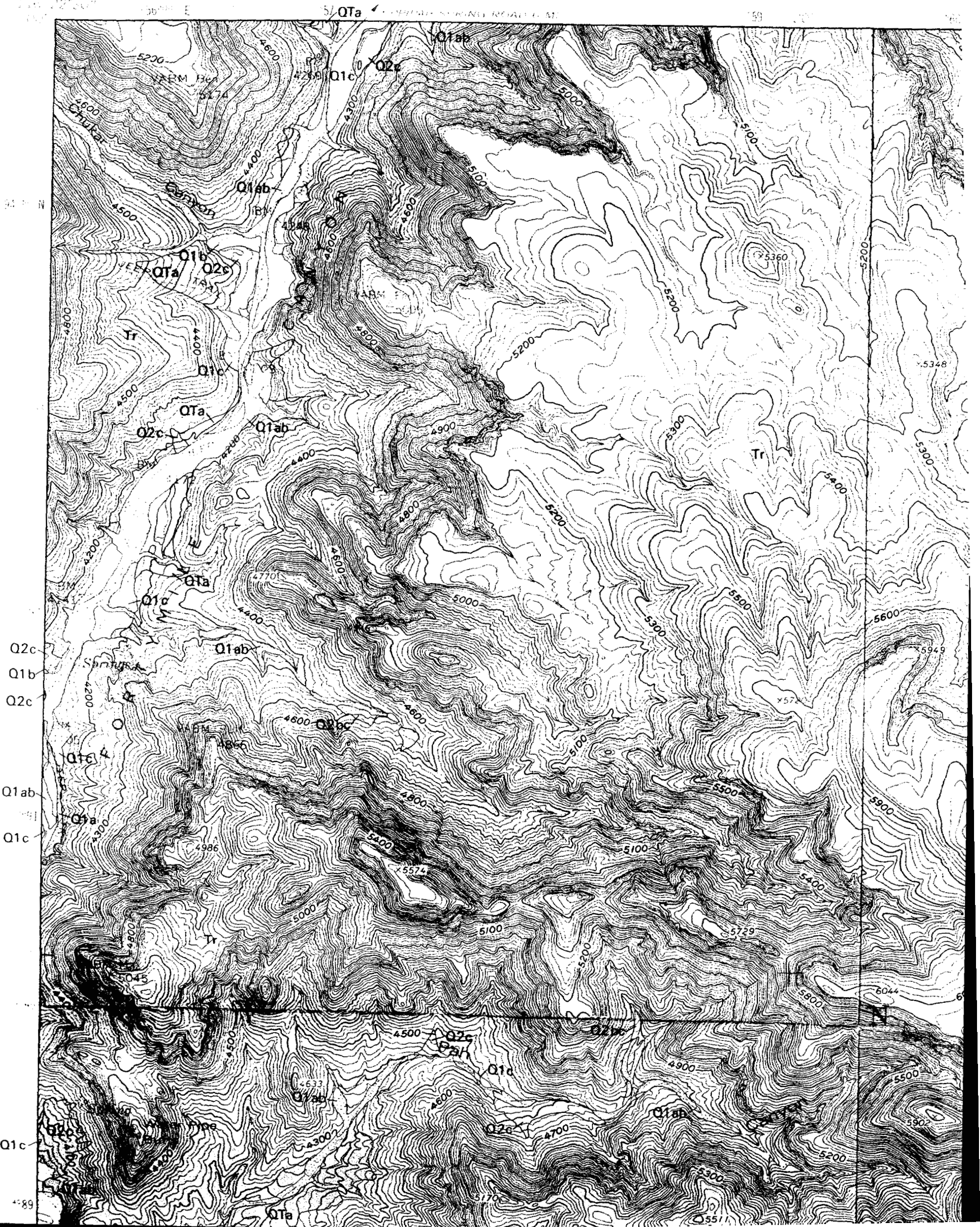




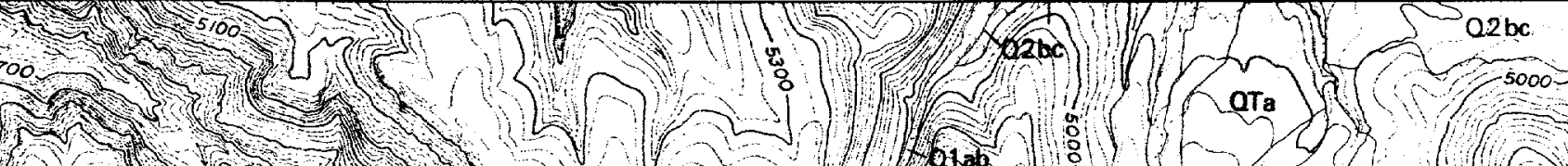
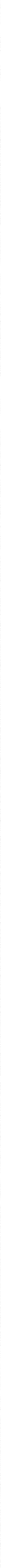


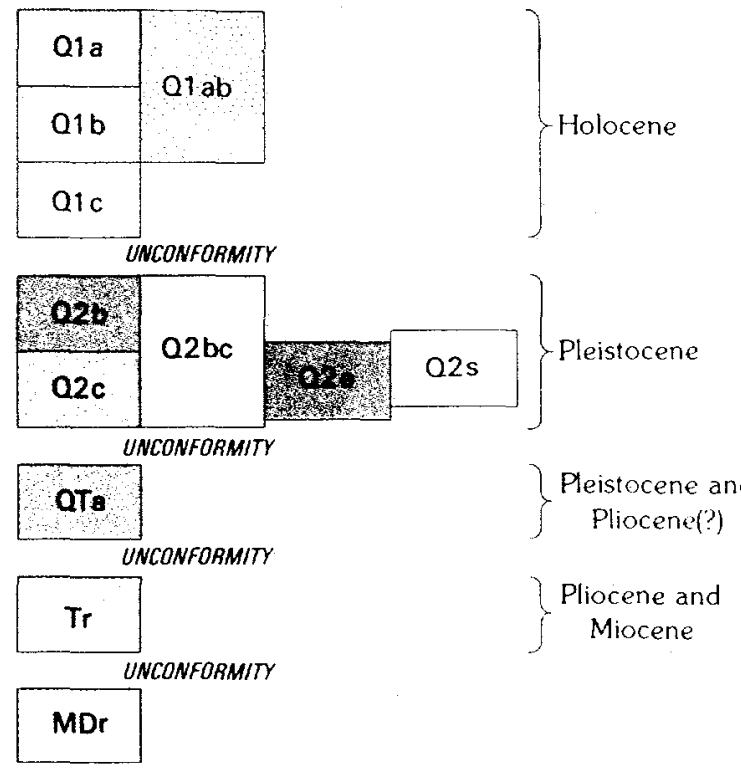

\section{DESCRIPTION OF MAP UI}

[Units are distinguished on the basis of lithology, surface morp deposition; these criteria are modified from Hoover and others ( 1

A combined map symbol $(\mathrm{O} 1 \mathrm{~b}+\mathrm{Q} 1 \mathrm{c})$ is used where two Quat such a small scale that separate mapping was impractical. The first condensed map symbol ( $\mathrm{O} 1 \mathrm{ab})$ is used where two stratigraphic combined unit. Where a veneer of the younger unit masks but underlying unit, a fractional symbol $\left(\frac{\mathrm{Q} 1 \mathrm{c}}{\mathrm{Q} 2 \mathrm{c}}\right)$ is used]

Holocene deposits-Alluvial deposits of pres age is inferred on the basis of limited so with Holocene deposits in nearby areas (H

Q1 a

Q1b

Alluvial deposits-Gravel, gravelly sand, s light gray to light brownish gray; poorly t to well bedded; unconsolidated; commor and lenses. Gravel is angular to subrou much as $1 \mathrm{~m}$ in diameter that are mos deposits. No soil development. Unit occu braided channels and gravel bars are c washes, such as Fortymile Canyon, most be mapped separately and are comb Maximum thickness probably less than

Alluvial deposits-Gravel, gravelly sand, light brownish gray; poorly to moderat bedded; unconsolidated; commonly oc lenses. Gravel is angular to subrounded $1 \mathrm{~m}$ in diameter. Boulders, as trains and in fans deposited on steep slopes. Unit form than $1 \mathrm{~m}$ above modern washes and downstream from incised parts of some and fans are very irregular, bar-and-s channels are common. Unit locally inc development is characterized by weak ox wide fans along some washes tributary to western part of quadrangle, $\mathrm{Q} 1 \mathrm{~b}$ depos spersed with channel deposits of 01 a th separately on this map; the two units are
unit 01 ab Thickness $0-5 \mathrm{~m}$, commonly 


\section{P UNITS}

\begin{tabular}{l|l} 
QUATERNARY \\
ene
\end{tabular}

\section{AP UNITS}

e morphology, relative age, and mode of thers (1981).

o Quaternary map units are interspersed at he first unit predominates in areal extent. A graphic units are commonly mapped as a isks but does not completely conceal the

of present drainage system. Holocene ited soil development and correlation areas (Hoover and others, 1981, p. 25) sand. silty sand, and thin lenses of silt; oorly to moderately well sorted; poorly ommonly occur as discontinuous beds subrounded and includes boulders as e mostly reworked from nearby $\mathrm{Q} 1 \mathrm{~b}$ it occurs in bottoms of modern washes; s are common. Except in some larger $\mathrm{h}$, most Q1 a deposits are too narrow to combined with unit $\mathrm{Q} 1 \mathrm{~b}$ as $\mathrm{Q} 1 \mathrm{ab}$. than $2 \mathrm{~m}$

sand, silty sand, and silt; light gray to hoderately well sorted; poorly to well nly occur as discontinuous beds and unded and includes clasts as much as $s$ and in prtches, are locally abundant in hit forms fluvial terraces commonly less s and thin sheets and narrow fans f some drainages; surfaces of terraces r-and-swale topography and braided lly includes debris-flow deposits. Soil reak oxidation in B horizon. Unit forms tary to Topopah Wash. Along washes in deposits commonly are closely interQ1 a that are too narrow to be shown hits are commonly mapped together as monly less than $2 \mathrm{~m}$
Q2s

OTa

Early Pleistocene and Pliocene(?) alluvial deposits-Chiefly unsorted cobble to boulder gravel; nonbedded to poorly bedded and moderately to well cemented by secondary carbonate. Unit is mostly debris-flow deposits and poorly sorted alluvium but locally includes fluvial deposits that are moderately well bedded, moderately well sorted pebble to cobble gravel with a silty sandy matrix. Gravel is angular to subrounded; includes boulders commonly less than $2 \mathrm{~m}$ in diameter. Unit forms alluvial fans flanking bedrock hills; fans are commonly dissected to form rounded, concordant ridges on upper slopes. Soil developed in unit QTa typically consists of a 2- to 3-m-thick carbonate horizon that has a stage IV carbonate development in upper part and includes silica lenses, and is locally overlain by remnants of a dark-reddish-brown argillic B horizon and by a more extensive vesicular $A$ horizon similar to that of soils formed in middle and late Pleistocene deposits. Surface of QTa deposits generally has a densely packed desert pavement that includes numerous tabular fragments of pedogenic carbonate and opaline silica. This pavement locally is continuous with pavements developed on adjacent $\mathrm{O} 2 \mathrm{c}$ deposits. No age determinations have been made for unit QTa. In the NTS area, a minimum age greater than $740 \mathrm{ka}$ is inferred based on the occurrence of OTa deposits that have a well-developed soil overlain by eolian sand deposits (unit O2e) that contain beds of the 740-ka Bishop ash bed (Izett, 1982)

Tr Tertiary rocks, undivided (Pliocene and Miocene)-Ash-flow tuffs, ash-fall tuffs, rhyolitic and basaltic lavas, and minor amounts of intrusive rock. Mapped and described by Orkild and O'Conner (1970) and Maldonado (1985)

MDr Mississippian and Devonian sedimentary rocks, undivided-Dolomite, limestone, and argillite. Mapped and described by Orkild and O'Conner (1970) and Maldonado (1985)

\section{Contact \\ - Fault-Bar and ball on downthrown side. Shown in bedrock only if fault offsets adjacent surficial deposits \\ - - Lineament-Faint linear alignment of vegetation or topography on aerial photography; possibly fault related}

\section{PURPOSE OF STUDY}

The study of the surficial geology of the Topopah Spring quadrangle was undertaken in order to locate faults that displace Quaternary deposits in this part of the Yucca Mountain region. Work was done in cooperation with the U.S. Department of Energy, Nevada Nuclear Waste Storage Investigations Project (Interagency Agreement DE-A108-78ET44802), and is part of an evaluation of a potential radioactive waste repository at Yucca Mountain, approximately $8 \mathrm{~km}$ west of the map area. Other areas included in the study of the surficial 
(a.9.

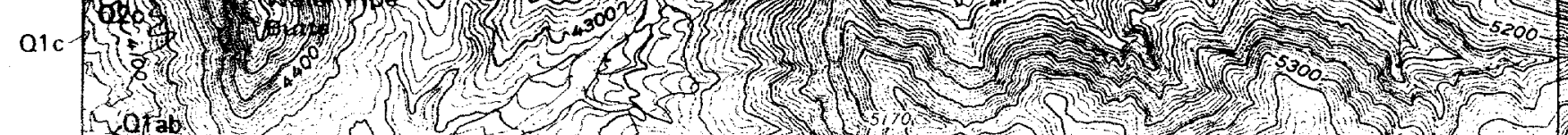
(n)

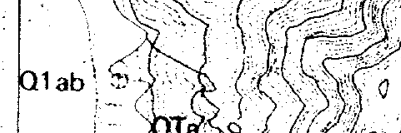

\section{$=$}

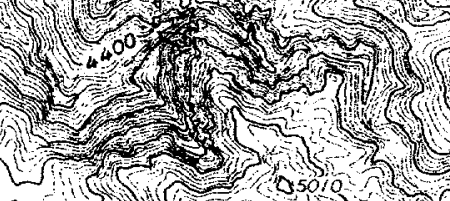

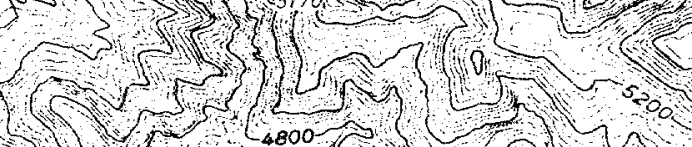
8 (n)

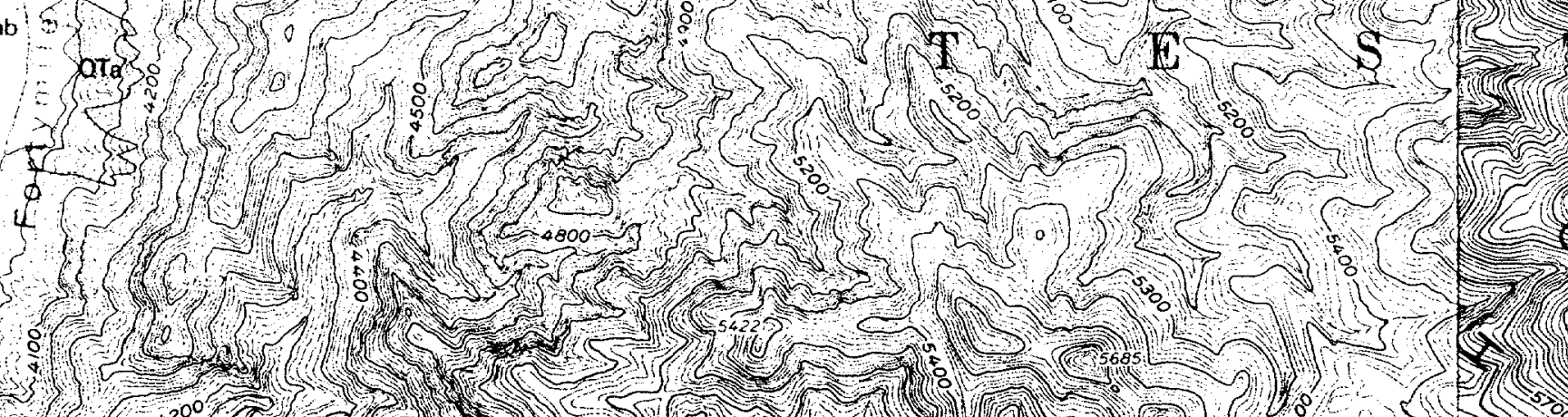

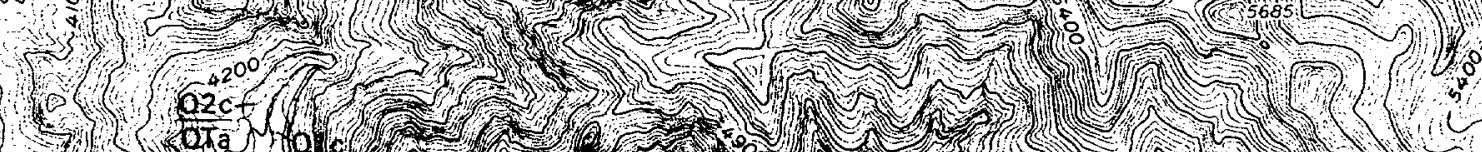

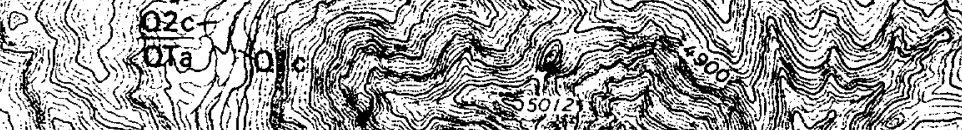

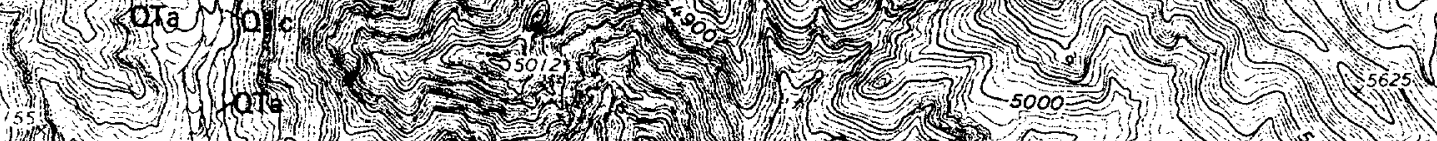
6

Q1 ab.

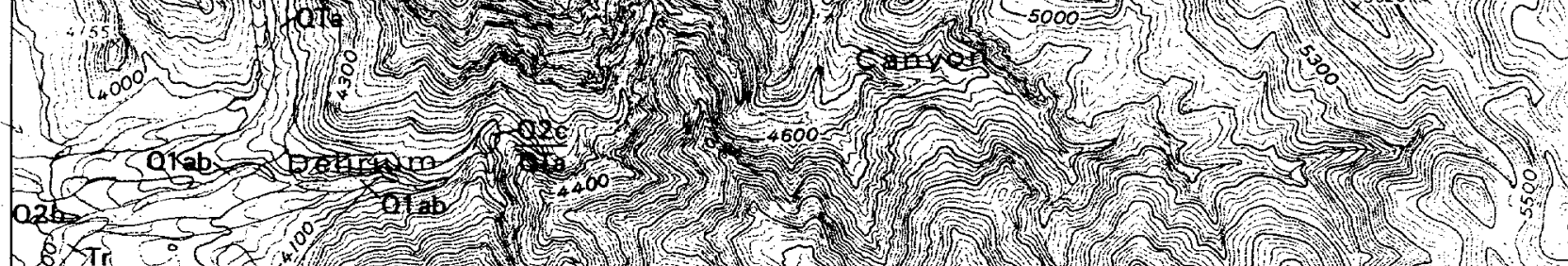

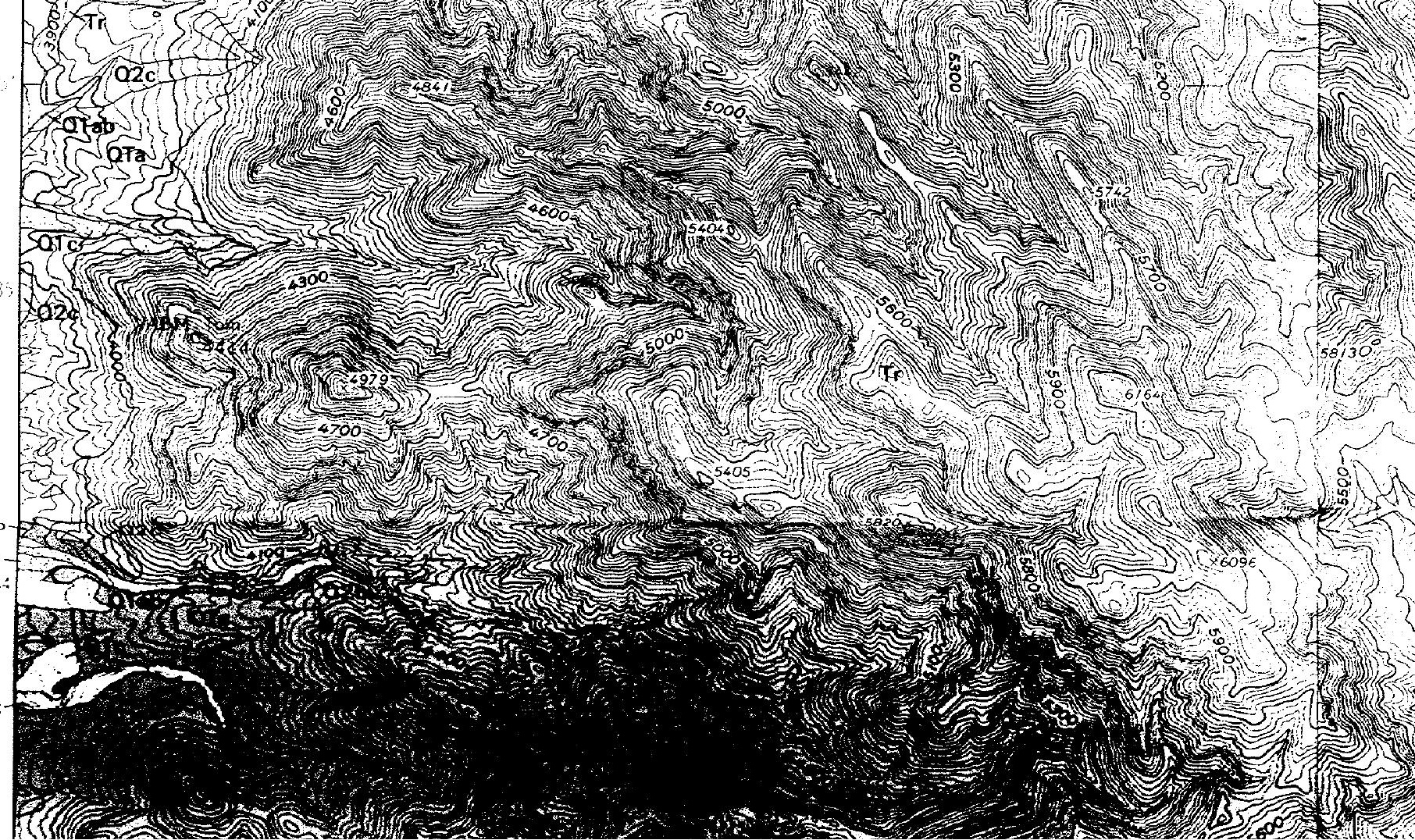




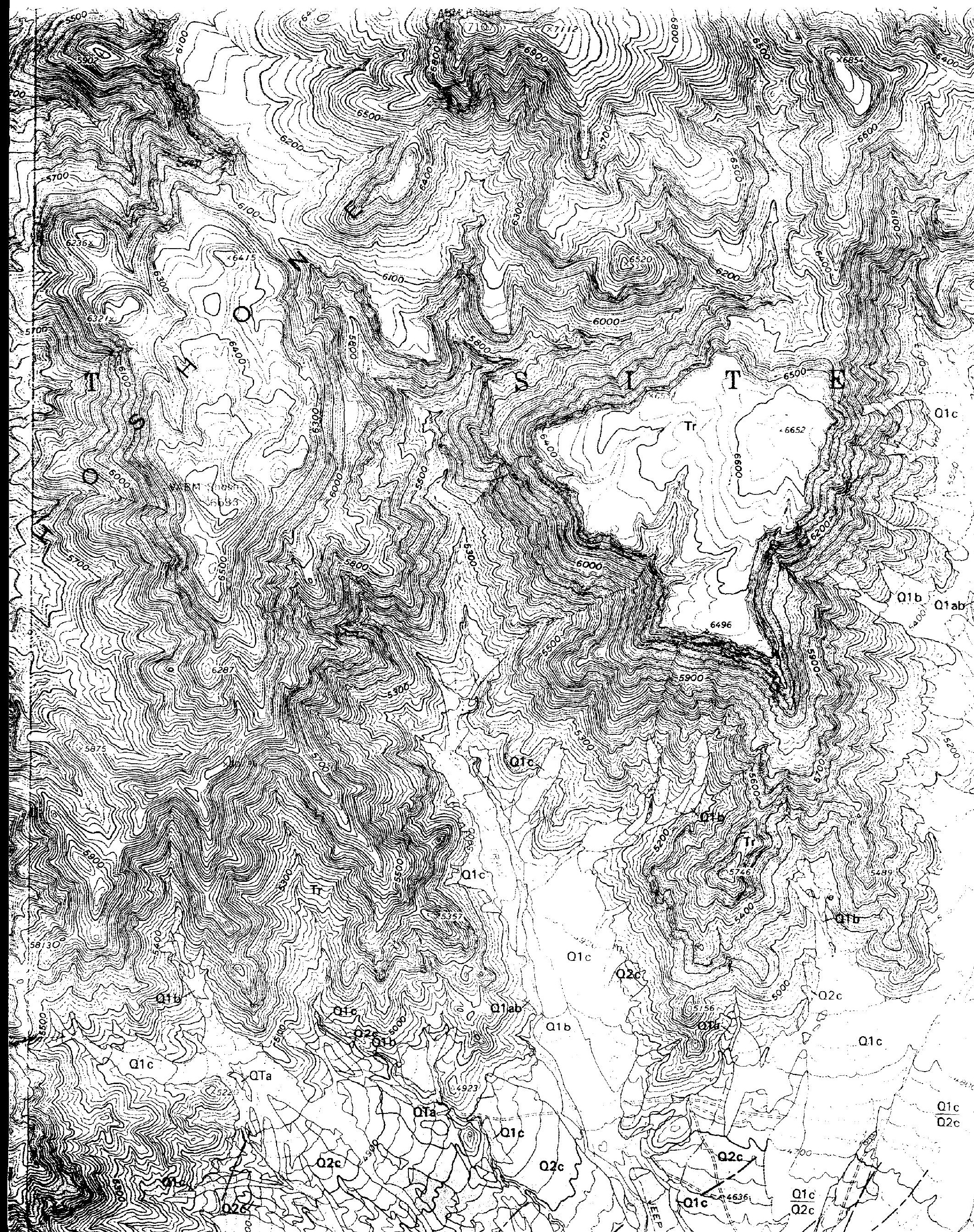




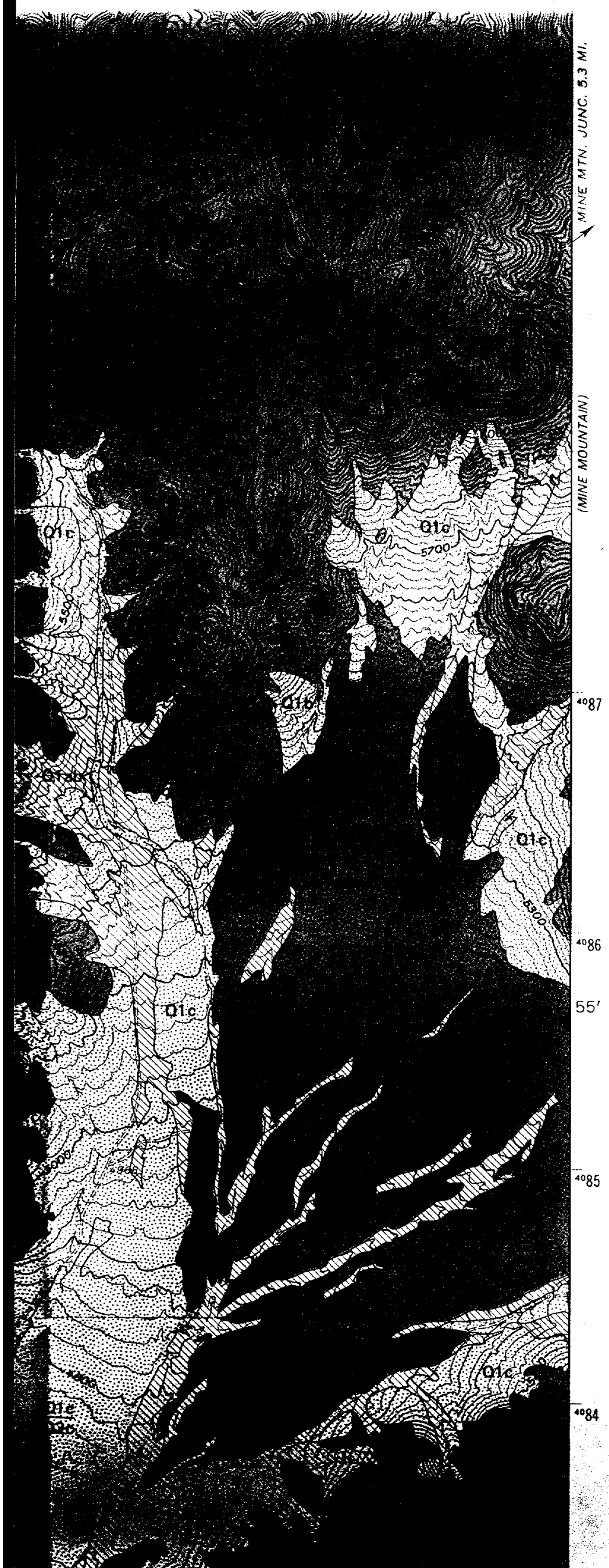

downstream from incised parts of some drain and fans are very irregular, bar-and-swale 1 channels are common. Unit locally includes development is characterized by weak oxidatiol wide fans along some washes tributary to Topop westem part of quadrangle, $\mathbf{Q 1} \mathrm{b}$ deposits cor spersed with channel deposits of Q1 a that are separately on this map; the two units are comn unit $\mathrm{Q} 1 \mathrm{ab}$. Thickness $0-5 \mathrm{~m}$, commonly less $\mathrm{t}$

0106

olc.

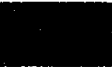

Alluvial deposits-Combined map unit used wl Q1 b are so closely interspersed that the two separately

Alluvial deposits-Gravel, gravelly sand, andisilty to pale yellowish brown; poorly to moderately bedded; slightly consolidated. Gravel is angu commonly less than $0.5 \mathrm{~m}$ in diameter, but unconsolidated. Unit forms discontinuous ter washes and thin fan deposits on units $\mathrm{Q} 2 \mathrm{c}$ an commonly smooth, in contrast to Q1 b. Soil der of minor leaching of calcium carbonate in I developed carbonate horizon (stage I of Gile an horizon characterized by thin carbonate ooat clasts $0.5 \mathrm{~m}$ or more below the surface. Locally, weakly developed surface lag deposit. Thickn

Late and middle Pleistocene deposits-Alluvial a Nevada Test Site (NTS) area, these deposits hi map units based on lithology, depositional envi as indicated by topographic position, amount o: soil development (Hoover and others, 1981). recognized in the quadrangle

Alluvial deposits-Gravel, sand, and silt; yellowis poorly to moderately well sorted; massive to weakly consolidated. Gravel is subangular to $\mathrm{r}$ less than $0.5 \mathrm{~m}$ in diameter. Sand and silt ogcur silty sand beds and lenses interbedded with grax has a light-brownish-gray vesicular $A$ horizo o co clay-size material, a light-brown cambic $B$ ho: carbonate horizon that commonly has carbona clasts and minor filling of voids. Desert paveme well packed. Unit forms small inset terrace remi of unit $\mathbf{0 2 c}$ along some of the large washes anc cut on older units along major drainages. Differ: development and generally lower topographic only in two washes near west border of quadr from adjacent Jackass Flats 7 1/2-minute $q$ Hoover, in press). A median age of about 170 $\mathrm{O} 2 \mathrm{~b}$ deposits on the basis of several age deter experimental uranium-trend method on sinila Mountain area to the west (Rosholt and others, 1 1984). Thickness $0-5 \mathrm{~m}$

Alluvial deposits-Gravel, sand, and silt, yellowi weakly to moderately well consolidated. Gravel well sorted, poorly to well bedded, angular. boulders commonly less than $1 \mathrm{~m}$ in diameter, $\mathrm{b}$ Sand and silt occur as matrix of gravel beds a gravelly sand and silty sand interbedded with! smooth fans on piedmont slopes and terrace $r$ incised into unit QTa and bedrock. Includes bo deposits. Soils of at least two ages have towelo older soils typically have a very pale brown vesic silicified reddish-brown argillic B horizon, and a carbonate horizon. The younger soils have a st about $1 \mathrm{~m}$ thick overlain by a less silicified horizon and a vesicular $A$ horizon similar to Typically both the older and younger soils al packed desert pavement. Commonly a well-dev, coats surface gravels that are derived from ve slightly older than $740 \mathrm{ka}$ has been inferred for the NTS area on the basis of its stratigraphic $r$

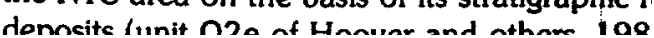


some drainages; surfaces of terraces -and-swale topography and braided thy includes debris-flow deposits. Soil eak oxidation in B horizon. Unit forms ary to Topopah Wash Along washes in deposits commonly are closely interOt a that are too narrow to be shown mits are commonly mapped together as monly less than $2 \mathrm{~m}$

9 unit used where deposits of 01a and hat the two units cannot be mapped

rand, and silty sand; light brownish gray - moderately well sorted; poorly to well covel is angular to subrounded; clasts Fameter, but locally as large as $1 \mathrm{~m}$; continuous terraces 1-3 $\mathrm{m}$ above most wits Q2c and QTa. Surface of Q1c is Q1 b. Soil development consists chiefly arbonate in upper part and a weakly me I of Gile and others, 1966); carbonate rrbonate doatings on bottoms of some rface. Locally, deflation has produced a posit. Thiekness 0-15 m

ts-Alluvial and eolian deposits. In the se deposits have been divided into five positional environment, and relative age Fon, amount of dissection, and degree of thers, 1981). Four of the five units are

d silt; yelldwish brown to grayish brown; d; massive to moderately well bedded; bangular to rounded; clasts commonly and silt occur as matrix in gravel and as dded with gravel. Soil developed in $\mathrm{O2}$ b A horizon composed largely of silt- and cambic B horizon, and a stage I to II $y$ has carbonate coatings on bottoms of esert pavement is loosely to moderately terrace remnants $0.5-2 \mathrm{~m}$ below level ge washes and occurs as strath terraces inages. Differs from $02 \mathrm{c}$ by weaker soil topographic position. Poorly exposed der of quadrangle. Description largely 1/2-minute quadrangle (Swadley and of about $170 \mathrm{ka}$ has been interred for ral age determinations made using the hod on similar deposits from the Yucca t and others, 1985; Swadley and others,

hd silt, yellowish gray to brownish gray; dated. Gravel is unsorted to moderately led, angular to subrounded; includes in diameter, but locally as much as $2 \mathrm{~m}$. gravel beds and in beds and lenses of bedded with gravel. Unit forms broad, and terrace remnants along drainages k. Includes both fluvial and debris-flow 5 have developed in 020 deposito. The le brown vesicular A horizon, a partially horizon, and a 1 - to 2 -m-thick stage IV soils have a stage III carbonate horizon ess silicified reddish-brown argillic B con similar to that of the older soils. unger soils are overlain by a densely nily a well-developed black rock varnish tived from volcanic rocks. An age of $n$ interred for lower part of unit $02 \mathrm{c}$ in tratigraphic relations with eolian sand d others 1981 which locally contai

\section{PURPOSE OF STUDY}

The study of the surficial geology of the Topopah Spring quadrangle was undertaken in order to locate faults that displace Quaternary deposits in this part of the Yucca Mountain region. Work was done in cooperation with the U.S. Department of Energy, Nevada Nuclear Waste Storage Investigations Project (Interagency Agreement DE-AI08-78ET44802), and is part of an evaluation of a potential radioactive waste repository at Yucca Mountain, approximately $8 \mathrm{~km}$ west of the map area. Other areas included in the study of the surficial geology of the Yucca Mountain region are shown in the index.

\section{REFERENCES CITED}

Gile, L. H., Peterson, F. F., and Grossman, R. B., 1966, Morphological and genetic sequences of carbonate accumulation in desert soils: Soil Science, v. 101, p. 347-360.

Hoover, D. L, Swadley, WC, and Gordon, A. J., 1981, Correlation characteristics of surficial deposits with a description of surficial stratigraphy in the Nevada Test Site region: U.S. Geological Survey Open-File Report 81-512, 27 p.

Izett, G. A., 1982, The Bishop ash bed and some older compositionally similar ash beds in California, Nevada, and Utah: U.S. Geological Survey Open-File Report 82-582, 47 p.

Maldonado, Florian, 1985, Geologic map of the Jackass Flats area, Nye County, Nevada: U.S. Geological Survey Miscellaneous Investigations Series Map 1-1519, scale 1:48,000.

Orkild, P. P., and O'Conner, J. T., 1970, Geologic map of the Topopah Spring quadrangle, Nye County, Nevada: U.S. Geological Survey Geologic Quadrangle Map GQ-849, scale 1:24,000.

Rosholt, J. N., Bush, C. A., Carr, W. J., Hoover, D. L., Swadley, W C, and Dooley, J. R., Jr., 1985, Uranium-trend dating of Quaternary deposits in the Nevada Test Site area, Nevada and California: U.S. Geological Survey Open-File Report 85-540, 72 p.

Swadley, W C, 1983, Map showing surficial geology of the Lathrop Wells quadrangle, Nye County, Nevada: U.S. Geological Survey Miscellaneous Investigations Series Map I-1361, scale 1:48,000.

Swadley, W C, and Carr, W. J., 1987, Geologic map of the Quaternary and Tertiary deposits of the Big Dune quadrangle, Nye County, Nevada, and Inyo County, California: U.S. Geological Survey Miscellaneous Investigations Series Map 1-1767, scale 1:48,000.

Swadley, W C, and Hoover, D. L., in press, Geologic map of the surficial deposits of the Jackass Flats quadrangle, Nye County, Nevada: U.S. Geological Survey Miscellaneous Investigations Series Map 1-1994, scale 1:24,000.

Swadley, W C, Hoover, D. L., and Rosholt, J. N., 1984, Preliminary report on late Cenozoic faulting and stratigraphy in the vicinity of Yucca Mountain, Nye County, Nevada: U.S. Geological Survey Open-File Report 84-788, 42 p.

Swadley, W C, and Huckins, H. E., in press a, Surficial geologic map of the Specter Range NW quadrangle, Nye County, Nevada: U.S. Geological Survey Miscellaneous Investigations Series Map 1-1884, scale 1:24,000.

in press b, Geologic map of the surficial deposits of the Skull Mountain quadrangle, Nye County, Nevada: U.S. Geological Survey Miscellaneous Investigations Series Map -1972, scale 1:24,000.

Swadley, W C, and Parrish, L. D., 1988, Surficial geologic map of the Bare Mountain quadrangle, Nye County, Nevada: U.S. Geological Survey Miscellaneous Investigations Series Map I-1826, scale 1:48,000.

$$
\text { . }
$$

$116^{\circ} 45^{\prime}$

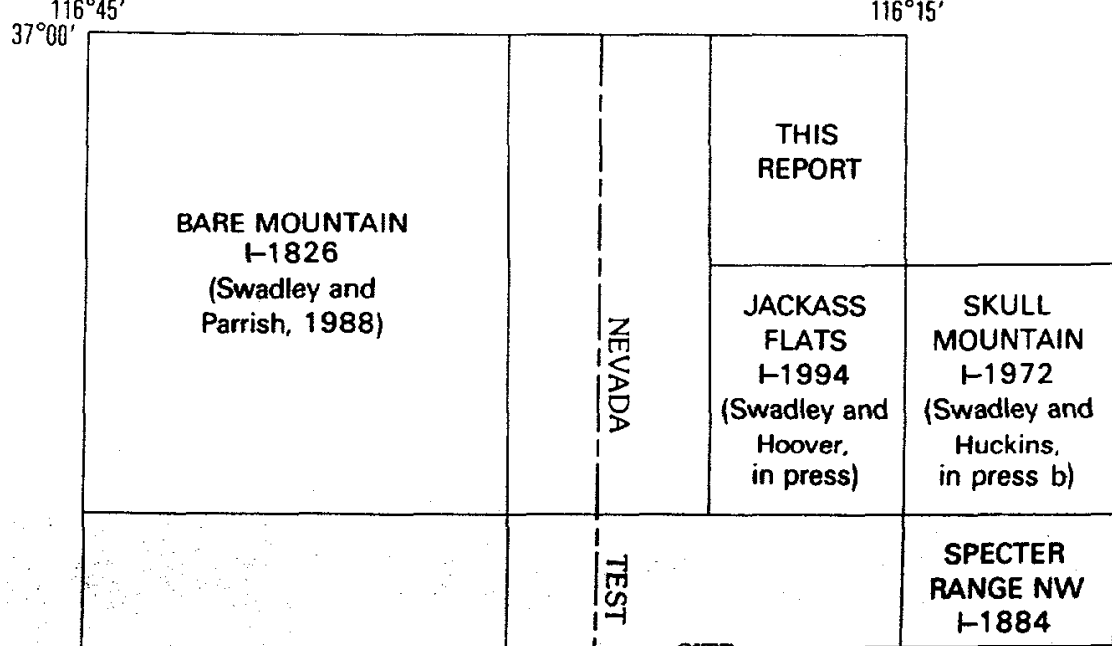




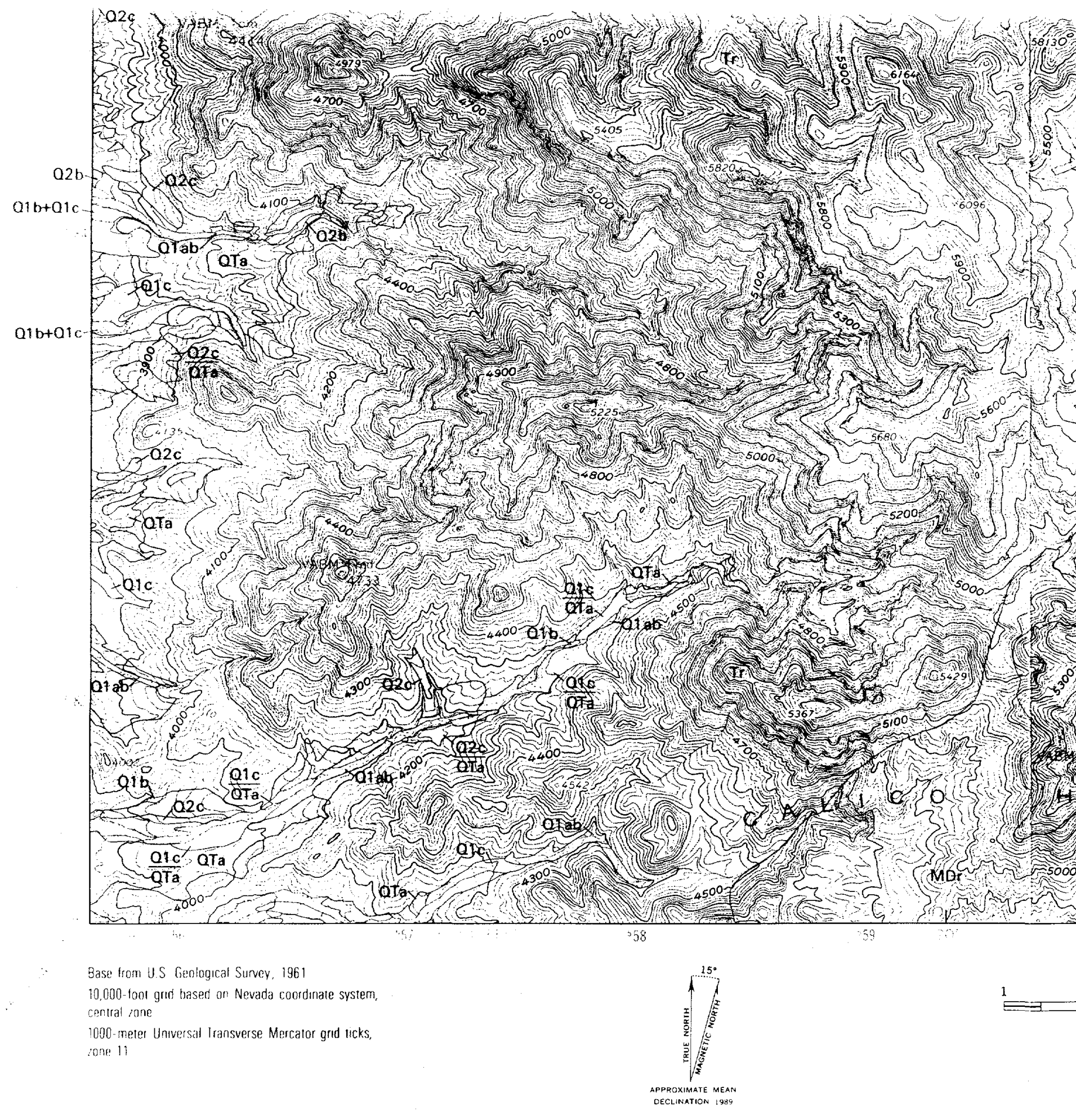

\section{GEOLOGIC}



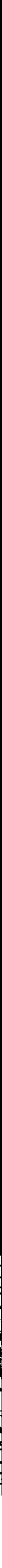

SCALE 1:24000

$1 / 2$ 1 MILE

NEVADA

1

1

0

1 KILOMETER

CONTOUR INTERVAL $20 \mathrm{FEET}$

NATIONAL GEODETIC VERTICAL DATUM OF 1929

QUSORANGLE LOCATIO:

PIC MAP OF THE SURFICIAL DEPOSITS OF THE T
w C Swadley 


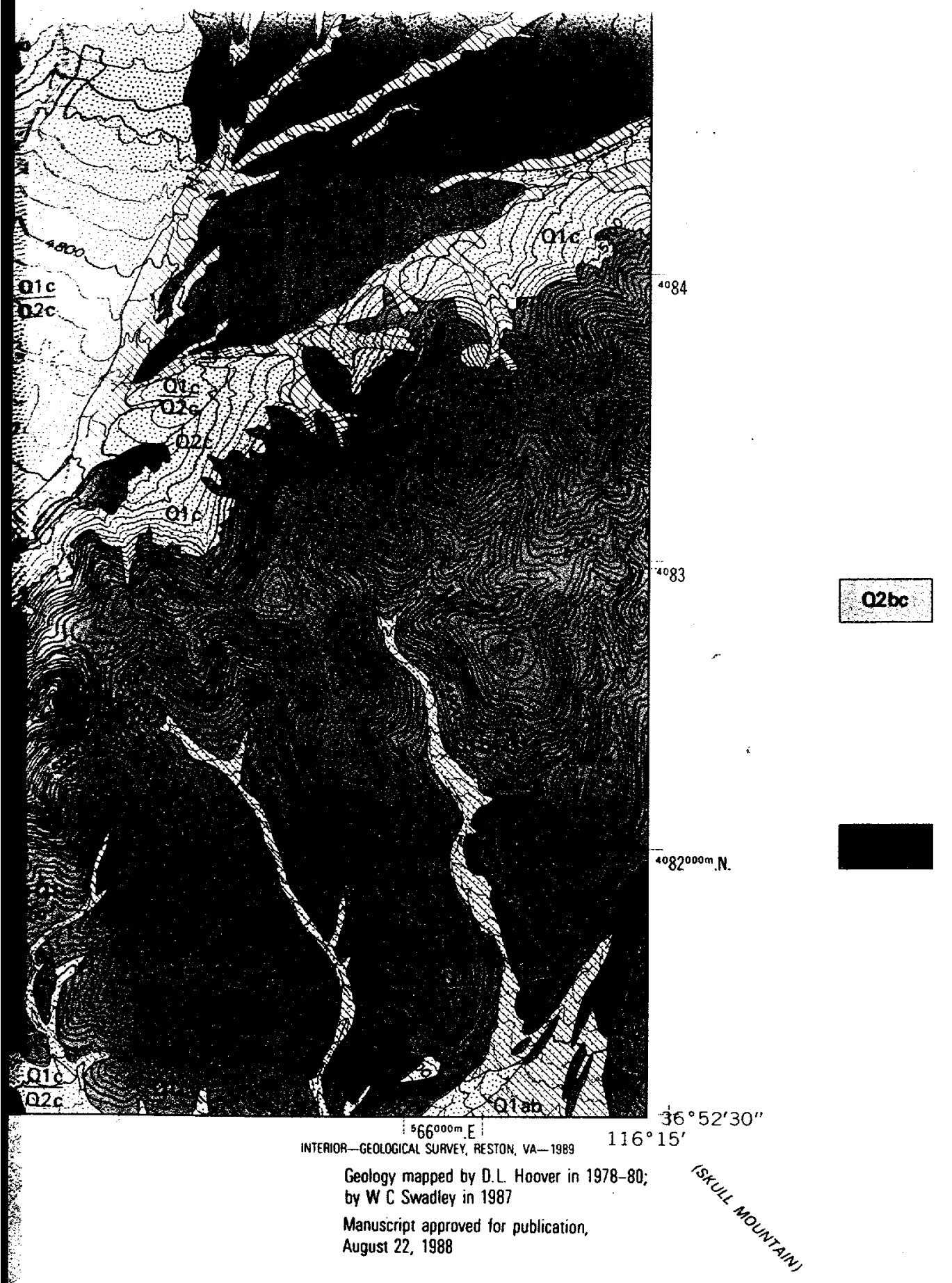

boulders commonly less than $1 \mathrm{~m}$ in diameter, but Sand and silt occur as matrix of gravel beds and gravelly sand and silty sand interbedded with grar smooth fans on piedmont slopes and terrace remr incised into unit QTa and bedrock. Includes both $f$ deposits. Soils of at least two ages have developed older soils typically have a very pale brown vesicula silicified reddish-brown argillic B horizon, and a 1carbonate horizon. The younger soils have a stage about $1 \mathrm{~m}$ thick overlain by a less silicified red horizon and a vesicular $A$ horizon similar to th Typically both the older and younger soils are c packed desert pavement. Commonly a well-develo coats surface gravels that are derived from volca slightly older than $740 \mathrm{ka}$ has been inferred for lou the NTS area on the basis of its stratigraphic relat deposits (unit Q2e of Hoover and others, 1981), beds of the 740-ka Bishop ash. Uranium-trend a 02 c deposits exposed in the Yucca Mountain area $270 \mathrm{ka}$ (Rosholt and others, 1985; Swadley and o inferred to be the minimum age of unit $\mathrm{O} 2 \mathrm{c}$ in this are

Alluvial deposits-Combined map unit used wher cannot be distinguished on the basis of top geomorphic form. Units are mapped separately drainages where $\mathrm{O} 2 \mathrm{~b}$ deposits are preserved as rem (some too small to show at scale of this map) adjace Locally, Q2b occurs as thin fan deposits that loca closely interspersed with deposits of $\mathrm{Q} 2 \mathrm{c}$ so as to $\mathrm{m}$ two units impractical. Where the two units ar commonly the more extensive component

Eolian deposits-Sand; very pale orange to light $b$ medium; well sorted; unconsolidated to weakly $\mathrm{c}$ locally varying amounts of eolian sand reworkec intermittent streams; these deposits contain scatte and gravel lenses. Near bedrock outcrops, sand com moderately well packed pavement of angular grave in two small areas near south border of quadrangl south in the Jackass Flats quadrangle (Swadley and) which this description is taken. In that quadrangle, $v$ of sand flanking bedrock hills, commonly on north- $c$ Exposures at Busted Butte, $10 \mathrm{~km}$ south-southwe: indicate that some of the larger ramps in the NTS at as five superimposed eolian deposits separated $b$ enriched soils. Surface soils formed in $\mathrm{O} 2 \mathrm{e}$ deposit 0.5 - to 1.0 -m-thick stage III carbonate horizon. Th

\title{
TOPOPAH SPRING QUADRANGLE, NYE COUNTY
} By

\author{
and D.L. Hoover
}

1989 
civendied win gravel. Unit forms oroad, s and temrace remnants along drainages ck. Inctude both fluvial and debris-flow es heve deueloped in $02 c$ deposits. The ale buonv vesicular $A$ horizon, a partially horiaen, and a 1- to 2-m-thick stage IV soils lave a stage III carbonate horizon less silicified reddish-brown argillic B izon similat to that of the older soils. ounger soils are overlain by a densely only a well-developed black rock varnish lerived from volcanic rocks. An age of en inferred for lower part of unit $02 \mathrm{c}$ in stratigraphic relations with eolian sand nd others, 1981), which locally contain Uravim-trend age determinations for ca Mountain area yielded ages of about 35: Swadley and others, 1984), which is unit $02 \mathrm{c}$ inthis area. Thickness $0-10+\mathrm{m}$ $p$ unit ased where units $02 b$ and $02 c$ he basis of topographic position or rapped separately in areas of incised e preserved as remnants of inset terraces of this map/ adjacent to deposits of 02c. deposits that locally overlie fans or are of 02c so as to make separation of the the two units are combined, $02 \mathrm{c}$ is omponent

orange to light brownish gray; fine to ated to weakly consolidated. Includes n sand reworked by slope wash and sits contain scattered pebbles, cobbles, itcrops, sand commonly has a loosely to tof angular gravel. Unit poorly exposed der of quadrangle; well exposed to the gle (Swadley and Hoover, in press) from that quadrangle, unit forms large ramps monly on north- or south-facing slopes. m south-southwest of this quadrangle, mps in the NTS area consist of as many osits separated by buried, carbonate$d$ in 02 e deposits typically consist of a mate horizon. Thickness $0-5 \mathrm{~m}$
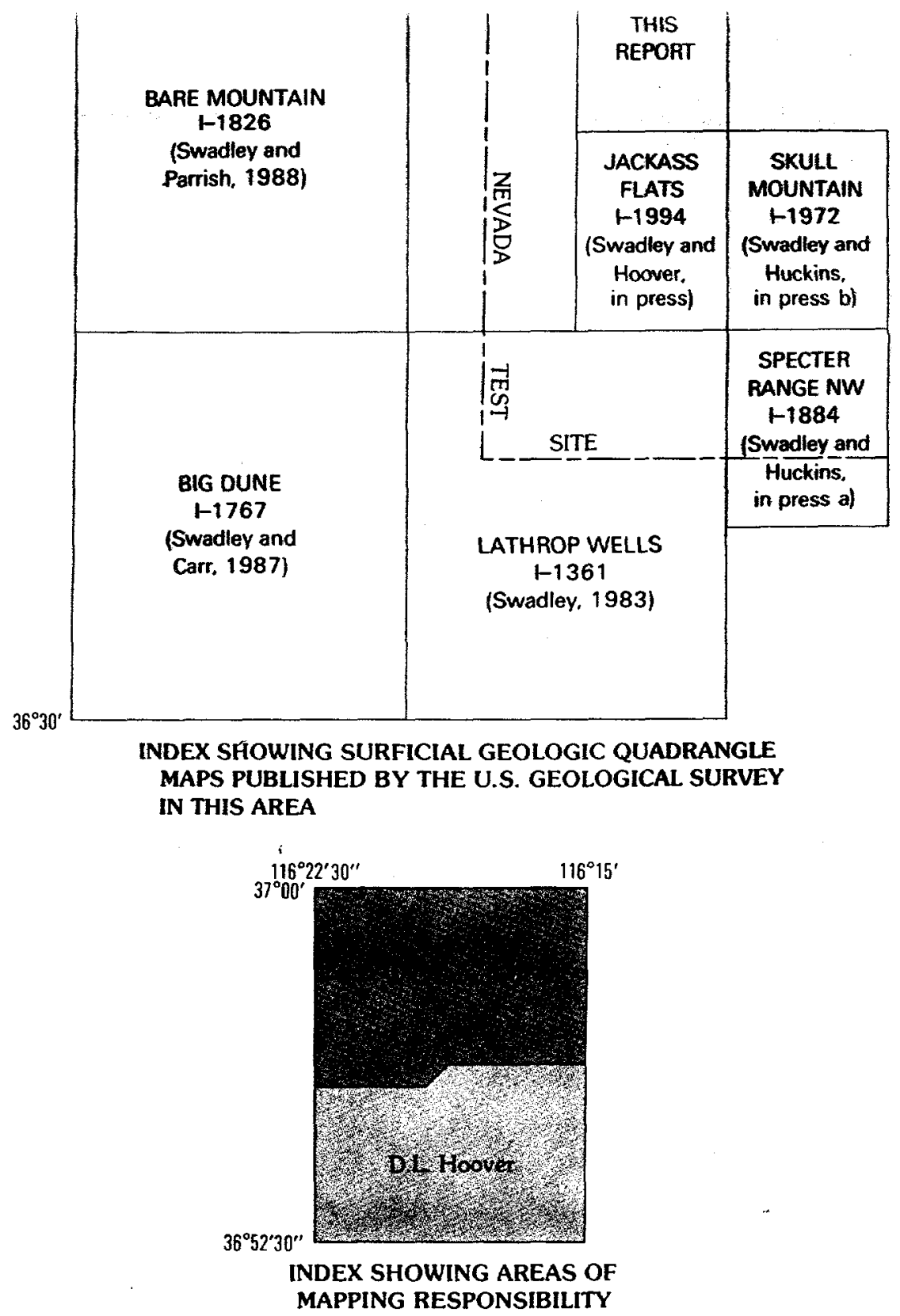